\title{
Performance Analysis of Manufacturing Industries for System Improvement
}

\author{
Alie Wube Dametew* and Frank Ebinger \\ Department of Mechanical Engineering and Industrial Engineering, School of Mechanical and Industrial Engineering, Addis Ababa Institute of Technology, Addis Ababa \\ University-Ethiopia and Technische Hochschule Nürnberg Georg Simon OHM, Germany
}

\begin{abstract}
This study is to investigate and evaluate the performance of basic metal industries, so as to know performance gaps and developing further research themes for sector improvement and changes required. Through industrial survey 86 Ethiopian basic metal sectors and literature review, were studied. Though, the study mainly focused on raw material utilization, production capacity, innovation and Technological capability, product demand and supply, import-export process, job creation and labor force and supply chain systems performances used as performance dimension on this investigations. Since, the main aim of the study is to investigated the challenges and identify the gaps of the sector that needs for further investigation and policy measures to enhance efficient and competitive metal sectors. Since, this study design to evaluate how basic metal industries were performing in their objective, role, goals and identify the areas where the action, improvement and changes required. Based on the investigation, we find that, in some extent the basic metal performance is good. Even though, the combined effects of each performance dimension results lower performing sector. This lower performance occurred due to high cost of international market, problems forging currency, logistics and public infrastructure, warehouse problems, outdated technology, system are the main constraints of the sectors. As result of this performance the overall GDP contribution of the sector is infant and only recorded on $0.4 \%$ of the five light manufacturing sectors. Finally the further research directions and theme were investigated and proposed.
\end{abstract}

Keywords: Performance; Basic metal sector; Capability; Performance dimensions; Research theme; Performance indicator

\section{Introduction}

The Ethiopian manufacturing sector had been progressive in the imperial period until the overthrow of the regime in 1974. During the following Dreg regime the private sector was discouraged because of nationalization of companies and the ceiling imposed on the amount of capital the private sector could invest. The economy was governed by a central command system which left limited space for market forces to operate. This results in slower progress in most sectors of the economy and economic growth was at its bare minimum [1,2]. In the meantime the government of Ethiopia liberalized the economy since 1991 and the government has designed and adopted agricultural development led industrialization strategy to enhance economic growth. However, the country's industrial development strategy, value adding private sector is considered the engine of the sectors' growth [2,3]. Accordingly, currently in Ethiopia light manufacturing industries, such as leather, textile, metal and cement are considered as strategic sub-sectors for the socio-economic development of the country [4]. This is because the nature and ability of the industries to absorb a significant labor force, contribute to export earnings and tendency to facilitate multiple linkage with the rural population in line with the country's industrial development strategy is paramount. In addition, the country endowment with rich source of raw material makes the sectors very important in competing in the international market. Even though Ethiopia is a land of huge natural resources, but we have improperly used these resources for the development. Due to various reasons the four light manufacturing industries were not properly used local resources for as an input on their manufacturing processes. As a result, they depend on imported materials rather than local resources. Consequently of these the manufacturing sector is still infancy and have full of problems. Also, even if, the tremendous efforts made and the economic growth achieved, the Ethiopian economy remains beleaguered by structural problems. In specific, study [3-7]. shows that, due to skill man power, problems infrastructure and financial constraints the Ethiopia basic metal industries is poor in market shear and GDP contribution to the country. But, till now there have been no efforts to study from a research perspective investigating the know the sectorial performance and impacts of supply chain in Ethiopian basic metal industries and very few studies also conducted on other manufacturing sector (like Textile and Lather). Since, this study is design do fill this gaps. Thus, the objective of this paper is to investigate the challenges and identify the gaps of the sector that needs for further investigation and policy measures to enhance efficient and competitive metal sectors. Our study provides an important contribution to the existing literature by looking into the sector trend analysis of basic manufacturing industries in Ethiopia.

\section{Research Methodology}

The study is conduct through industrial survey and literature review of the previous research works and investigations which are discuss related to manufacturing industries growth, performance, economic contribution, challenges, strengths and performances were assed. The study and analysis mainly focused on the performance of raw material, production performance, demand and supply performance, job creation and employment opportunity, import-export and innovation and technological capability for Ethiopian basic metal industries were

${ }^{*}$ Corresponding author: Alie Wube Dametew, Doctor of Philosophy (PhD) Candidate in Mechanical Engineering and Industrial Engineering School of Mechanical and Industrial Engineering, Addis Ababa Institute of Technology, Addis Ababa University-Ethiopia and Technische Hochschule Nürnberg Georg Simon OHM, Germany, Tel: +251913032751; E-mail: wubealie@gmail.com

Received August 24, 2017; Accepted September 25, 2017; Published September 30, 2017

Citation: Dametew AW, Ebinger F (2017) Performance Analysis of Manufacturing Industries for System Improvement. Ind Eng Manage 6: 228. doi:10.4172/21690316.1000228

Copyright: (c) 2017 Dametew AW, et al. This is an open-access article distributed under the terms of the Creative Commons Attribution License, which permits unrestricted use, distribution, and reproduction in any medium, provided the original author and source are credited. 
investigated in detail. Since, the investigation consider attempts to explore the challenges, opportunities of each performance dimensions were assessed, so as to improve the performance and efficiency of the sectors. Followed the summery, conclusion and further directions were done. Since, the performance analysis of this study, the researcher mainly uses SPCS tools like Cause and effect (pareto analysis), and descriptive analyses are used (Figure 1).

\section{Literature Reviews}

\section{Manufacturing industry performances}

The result, success or the failure of a particular business process is evaluated by performance analysis. The performance analysis measurement provides to, sustain or modifying the process or procedure to increase the output, increase efficiency, or increase the effectiveness of the process or procedure [8]. This,performance analysis involves the determining and evaluating the past trends, the excising situation of manufacturing industries. Although, the evaluation provides to assessing progress toward achieving performance expectations, investigate and explain the causal relationships that exist between program activities and outcomes, correlating the current output to global trends were done [9]. Though, performance analyses were done in different scenario. Since, each performance dimensions were investigated and analysis based on cost and price, with quality and quantity, Profitability, environmental impact, the performance of physical quantity, product Varity, technological availability and technological capacity. But depending on the type of performance dimensions, it may or may not use each at a time. for instance, production performance, evaluated on product quality and quantity, product Varity, production time, whereas employment performance evaluated interims of, skill, number of employer engaged, leadership considered. Evaluation of an organization's goals and objectives with its actual working process or performances. As well, some dimension that considered to measure through traditional financial measures, internal efficiency, or market performance. Others evaluated interims of technological capability performance including existence of R\&D activities, skill and knowledge transfer [10]. As well, technological capability investigate as driving power on new product development of manufacturing industries [11]. Also, provides to the opportunity for organizations to express what they feel they have to achieve and to identify the eras that needs for improvements. Since, organizational performance measured, interims of manufacturing productivity, efficiency, profitability, sustainability of the firm, labor force, product quality, market value, and competitive advantage [12].
Since, performance evaluation system is not the same on different firms but it is firm based and organizational concerns. As a result in this study, they synthesized and analysis for raw material performance, production capacity, product demand and supply, job creation and labor force, GDP contribution, import-export recitation, innovation and technological capability were considered the key performance dimension and each performance dimension also decompose into various performance indicators.

\section{Impacts of manufacturing performance on economic growth}

The impacts of manufacturing sector on economic growth and development based on Kaldorian approach were investigated [13]. According to the study, increase in the share of the manufacturing sector enables to improve and national economy to grow at a faster rate. This indicates that, improve manufacturing sector provides to increase the performance and competitiveness of the country. Since, industry performances have positive impact on economic growth and development. As well [14], found and evaluate the productivity trend over time, for multi-inputs and multi-outputs production units manufacturing sectors. According to the result, top performing industries were driven by technological improvements or frontier effects. Though, technological improvements have great impact for the improvement of the industries as well. Also [15] investigate the productivity of manufacturing industries by considering labor productivity as performance indicator of the firms were done. As the study found that the firm size, human capital, and capital intensity factors affect the labor productivity of the manufacturing industry. The technical efficiency of large scale manufacturing industries in Pakistan was analyzed [16]. The study found that workers skill level has positive impact on technical efficiency. whereas market size does not have any significant impact on technical efficiency of manufacturing firms. The numerous studies in this analysis shows that, the analysis and evaluation of performance of manufacturing industries have a great impact, to know the current process and make remedial action if it is necessary. Since, improve manufacturing industries have critical influence on fast economic growth and development. In the meantime, depending on firm type the evaluation and performance of manufacturing industries are different including technical efficiency [16], productivity, technological improvement [15] were considered. Thus, to know and evaluate how basic metal industries were performing in their objective, role, goals and identify the areas where the action, improvement and changes required are the main issue for manufacturing sectors. Hence,

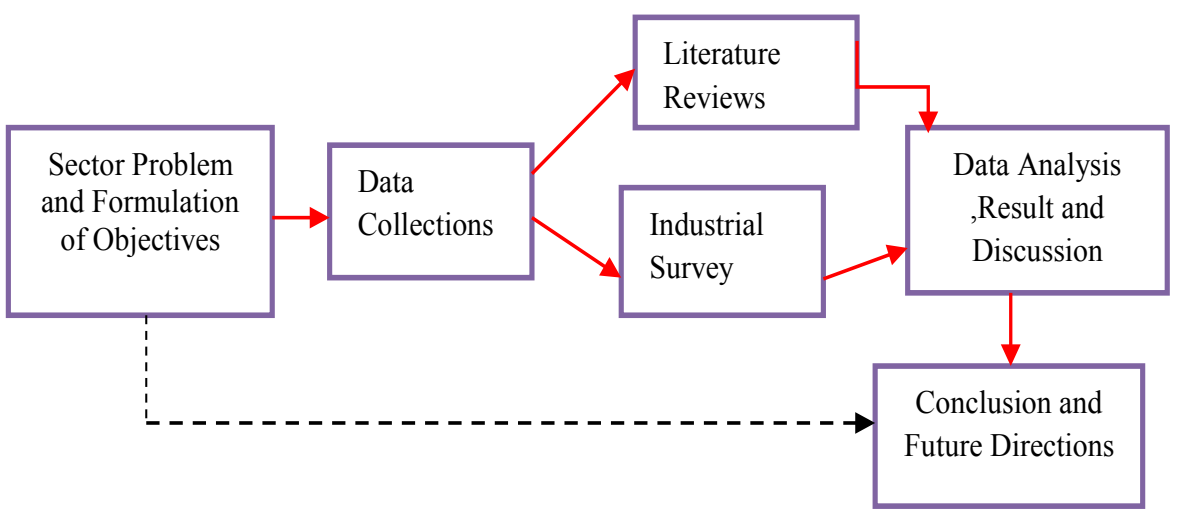

Figure 1: Research methodology frame work. 
this study is vital for the improvement and comparative advantages of Ethiopia basic metal industries.

\section{Result and Discussion}

Although, organizational performance evaluation provides necessary information to decision makers and plays a role in monitoring performance, enhancing competitiveness, improve communication, diagnosing and solving organizational constraints. However, in this section the detail analysis, evaluation, and discussion of the performance extent of basic metal industries were done. They synthesized and analysis were consider the performance of raw material, production capacity, product demand and supply, job creation and labor force, import-export performance, innovation and technological capability were considered as the key performance dimension. While, each performance dimension also decompose into various performance indicators. Since, in each stage of analysis the current situation of the sector measured based on their design or desire goal and objectives of the industry and the country as well. Though the performance analysis were done base on the following flow diagrams (Figure 2 and Table 1).

\section{Raw material performance}

Steel manufacturing industries are normally upstream technologies that cater to the requirements of downstream technologies through providing the required raw material in sufficient quantity and acceptable quality. Ethiopia will for the foreseeable time remain reliant on steel import for the lack of domestic iron ore mining and primary ore processing technology and continue to be exposed to world market steel price trends and competition until domestic capacities are build. Hence, long lead times for orders and the prevailing cash shortage in the business relative to increased world market steel prices may continue to cause supply shortages [17]. According to previous studies, $[3,17]$ in Ethiopia promising ore site exists in West Ethiopia, with 22 million tons of ore with high content of pent oxide vanadium $\left(\mathrm{V}_{2} \mathrm{O}_{5}\right)$ and titanium oxide $\left(\mathrm{TiO}_{2}\right)$ potentials. Since, in the near future the Ethiopian steel manufacturing sectors has being advantages for this resource their raw material shortage improvements. However, currently the local scrap cost raised from 2.50 birr to 8.50 birr because of improper way of reaching the scrap to the industry and informal merchandizes. Since metal sectors mainly depend on imported raw materials rather than local extraction. But currently, international materials are challenges for local companies. These are due to high cost of international market, problems forging currency, logistics and public infrastructure cost increased. As a result, the raw material performance of basic metal industries is poor (Figure 3).

The figure above shows that the ratio of the cost of imported raw materials to the total cost of the industry consumed in the production year of 2011/12-2015/15. Form the figure observed that, above $75 \%$ manufacturing industries were depend on imported raw materials. But currently the is problems on financial deficiency, forging currency concentrates at the country wide. As a result they count purchase more materials from international markets. Since, instead of increasing the performance of basic metal industries were decreased. On the other $30 \%$ of local material only depend on scraps. The local scraps also have allots of problems, including quality, availability, the way and systems of collecting systems. From numerous quality and availability of local scarp materials are the main challenges of the sector, are investigated. Then to improve the overall material constraints it needs for urgent and remedial actions the sectors.

\section{Production capacity and performance}

Basic metal production process follows a numerous working procedure including the removing impurities such as sulpher, phosphorus, and excess carbon from iron and adding alloying elements

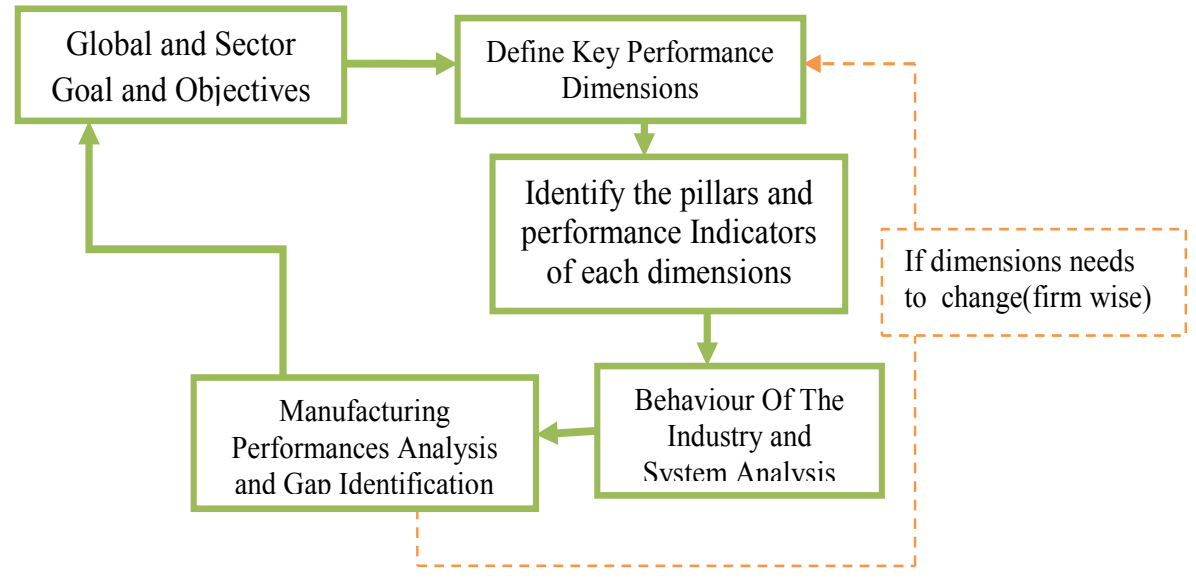

Figure 2: The analysis and evaluation procedures.

\section{Elements of Manufacturing Performance dimensions}

Raw Material

Production Capacity

Product Demand and Supply

Job Creation And Labor Force

GDP Contribution

Import-Export Situation

Innovation and Technological Capability

\section{Performance indicator}

Utilization, quality and quantity

Rate, Varity, quality, manufacturing system and technology

Quality and quantity

Number of workers, quality, capacity building programs, turnover

Financial performance, competitiveness,

Quality, quantity, market shear

R\&D, Knowledge and Skill, Systems, experience, number of new product development records.

Table 1: Key performance dimension and their performance indicators. 
Citation: Dametew AW, Ebinger F (2017) Performance Analysis of Manufacturing Industries for System Improvement. Ind Eng Manage 6: 228. doi:10.4172/2169-0316.1000228

Page 4 of 9

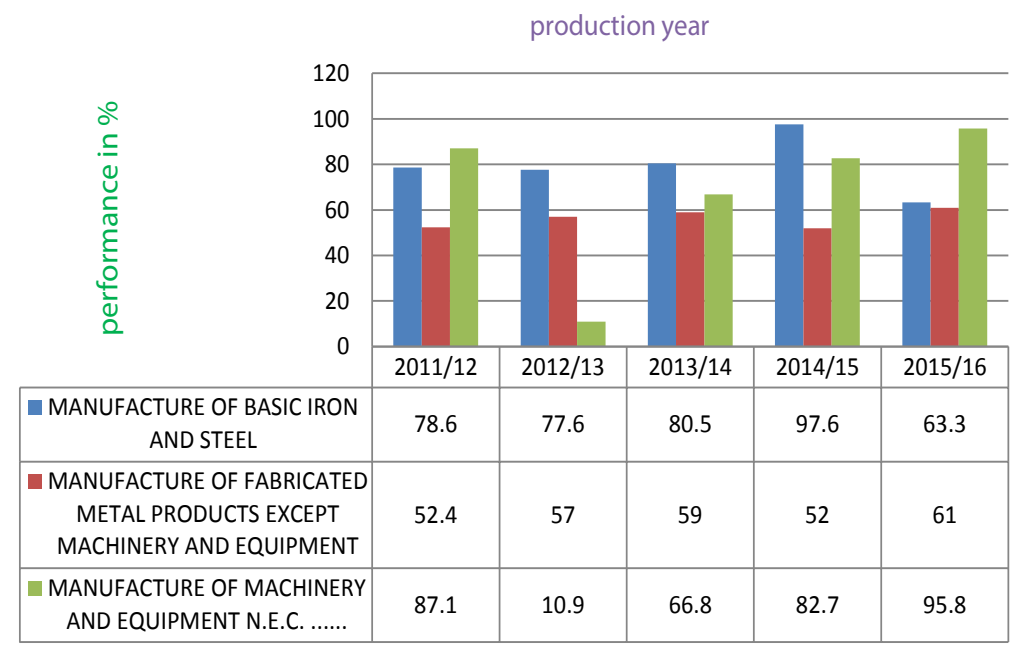

Figure 3: The percentage of imported materials.

\begin{tabular}{|c|c|c|c|c|c|c|c|c|c|}
\hline No & Type of products & Design Capacity & Measuring & 2010/11 & 2011/12 & $2012 / 13$ & $2013 / 14$ & $2014 / 15$ & $2015 / 16$ \\
\hline \multirow[t]{2}{*}{1} & \multirow[t]{2}{*}{ Reinforcement bars } & \multirow[t]{2}{*}{$1,191,860.00$} & Plan (Ton) & & & & & $552,492.27$ & $732,299.24$ \\
\hline & & & Actual (Ton) & $91,124.00$ & $138,846.00$ & $47,956.00$ & $228,588.43$ & $386,269.70$ & $454,285.60$ \\
\hline \multirow[t]{2}{*}{2} & \multirow{2}{*}{$\begin{array}{l}\text { Hollow sections and } \\
\text { steel profiles }\end{array}$} & \multirow[t]{2}{*}{$456,071.21$} & Plan (Ton) & & & & & $82,177.15$ & $161,972.33$ \\
\hline & & & Actual (Ton) & 22896.5 & 48,592 & 49657 & 66151.58 & $48,641.81$ & $78,849.53$ \\
\hline \multirow[t]{2}{*}{3} & \multirow[t]{2}{*}{ Roofing sheet } & \multirow[t]{2}{*}{$460,029.00$} & Plan (Ton) & & & & & $209,915.81$ & $279,328.72$ \\
\hline & & & Actual (Ton) & 83995.66 & 129455.11 & $162,214.05$ & $121,752.00$ & $144,018.71$ & $161,446.48$ \\
\hline \multirow[t]{2}{*}{4} & \multirow[t]{2}{*}{ wire and nails } & \multirow[t]{2}{*}{$85,200.00$} & Plan (Ton) & & & & & $60,131.53$ & $72,753.65$ \\
\hline & & & Actual (Ton) & 18413.29 & 24539.035 & 30,136 & $38,531.03$ & $34,117.71$ & $30,646.77$ \\
\hline \multirow[t]{2}{*}{5} & \multirow[t]{2}{*}{ Aluminum profiles } & \multirow[t]{2}{*}{$8,100.00$} & Plan (Ton) & & & & & $1,252.68$ & 798 \\
\hline & & & Actual (Ton) & 120 & 300 & 445 & 334.79 & 468.42 & 546.57 \\
\hline
\end{tabular}

Table 2: Designed and actual Steel production performance of basic metal industries.

such as manganese, nickel, chromium, and vanadium to produce the exact steel required. Since, steel mills turn molten steel into blooms, ingots, slabs, and sheets through casting, hot rolling, and cold rolling. Although the molten steel cast into large blocks of steel is called blooms. During the casting process various activities such as addition of aluminum so that impurities in the steel float to the surface where they can be cut off the finished bloom are done. However, Ethiopian basic metal industries deal with production of metal from ore, scrap and conversion of billet, slabs etc. into primary metal products such as, tubes bars, hot rolled ribbed and plain reinforcement bars, wire rod, angles, cold rolled tubes of various profiles, cold rolled sheets, galvanized sheets and tubes. The primary metal products produced by basic metal industries are subsequently raw materials (inputs) for the downstream engineering industries. On the other hand, International Steel Administration 2016,WSA, Deloitte Report 2015 (Russia) report shows that globally, steel production totaled 1.1 billion metric tons in 2005 and by 2015 had grown 41.4 percent to 1.6 billion metric tons an increase of 475 million metric tons over ten years. Although, the global production dipped in 2009 following the global financial crisis but rebounded quickly by 2010. In 2014, global production hit a record high of 1.67 billion metric tons. Weak global demand for steel in 2015 caused a slight contraction in crude steel production worldwide, decreasing 2.8 percent from 2014. According to the repot the steel production is increase, particularly the emerging country steel in more faster than the developed nations. This indicates that the economic growth also shifts to this countries. But the developing countries steel production is still infancy. However, in our filed study the production capacity were measured interims technical efficiency, technological utilization, product Varity, quality, change management systems and technological efficiency were incorporated. Since In our industrial assessment we observed that, the problems of low production capacity mainly related to poor infrastructure (electric power, outdated technology, problems on man power, warehouse problems were the main constraints of the sectors. In addition to this, most basic metal industries were not implemented and used advanced production improvement systems (like kaizen, TQM, Six Sigma). As a result the production performance is poor (Table 2).

Study shows [18] that in manufacturing industries, the success factors of local production and distribution of goods are related to the availability of locally produced cost-competitive and quality raw materials and other inputs. Even though, from the table above indicates that even if the production efficiency on basic metal industries had some improvements from year to year but the planned and the actual production capacity have great differences and variations. This indicates that the overall performance of basic metal industries going to back-warded. The major causes of the low production registered by domestic manufacturers were - the lack of strategic management and insufficient skill levels of employees; low linkage among industries; low level of technological development; inadequate provision of public infrastructure and services; shortage of electricity; shortage of hard currency; lack of trust in the local capacity, lack of raw materials and a cumbersome process at customs. As a result the global competition of the sector still infant and null. 


\section{Product demand and supply performance}

The demand and supply of basic metal product were analyses based on the past trend and the consumption of the country. However, table below provides as an indicator for the past and the current scenario of the county basic metal demand and supply. Since, this, scenario is used as an indicator for future growth and development of basic metal industries. As well, the situation gives directions and the practical performance of basic metal industries for the development of improvement strategies in local steel production, consumption (Table 3).

The table above shoes that, the projected demand for the basic metal products exceeded the actual supply throughout the projected years of 2011/12-2016/17. Even if there is incremental change in both demand and supply but there is deficiency of supply to achieve the demands of the country metal .However according to clearly shows that the supply and the quantity of imported products is much greater than that of local products. Due to insufficient production capacity in the basic metal industries, basic metal product supply shortage occurred in the country. Based on filed observation and literature survey data of this study indicates that insufficient raw material, power supply fluctuations, old production and manufacturing processes, information shearing, improper leader ship systems, infrastructure problems (landlocked), and poor quality management systems (TQM, Kaizen etc.) are the major constraints investigates in basic metal industries.

\section{Innovation and Technological capability}

Technological change is recognized as one of the main drivers of long-term growth and development of firms. As well, the development of improved manufacturing systems and strategies highly depend on innovation and technology [19]. Though, the knowledge, skill of technological capability provides to operate existing manufacturing systems and to generate technological development and providing technical changes for the organizational improvements. In the time of globalization and digital economy, improve the innovation of mobile internet, the internet of things and cloud computing are likely to revolutionize production processes and enhance living standards peoples. Since, innovation and technological capability is an important factor for the contributing of manufacturing industries to the economic growth [19]. Because technological capability provides to management and utilizing of technology, skills, manpower, knowledge, experience, institutional structure, integrating process and systems for the required and expected purposes to achieve the comparative advantage of the firms [10]. Even though, this study found that technological capability of basic metal industries are poor. Technological in efficiency is found in different reasons. In the field study we observe that, most Ethiopian manufacturing industries have not R\&D centers to develop, commercialized their products, experimenting, investigating new production system and strategies. Even, the quality of their products are not properly tested, and inspected, due to lack of testing and centers, problems of willingness. In addition, the effects of poor technological capability interims of innovation and technology transfer is related to the mechanism of technology transfer, the nature of technology, potentials of skill manpower (academic qualifications of employees, problems on the systems, and financial constraints are the common.
In addition, the challenge of institutional capacity, worse governance systems, lack institutions and regulatory frameworks also hampered to the innovation and technology transfers of the sectors.

\section{Job Creation and employment opportunity performance}

In any organizations man power and work force plays a crucial role to enhance the productivity and improve performances. As well, in specific basic metal and metal engineering industry machines and technologies relatively complexity, they needs equipped, required knowledge and skillslabor forces. As a result, the Ethiopian governments, giving priority for experts developments in science and engineering fields, to graduated from home universities and technical institutions. As a result the number of graduated increase and interesting progress as a country. The table below shows that that, number man power in the basic metal and engineering industries are improving from year to year and the average number of man power joining the sub sector annual is over 2000 from $2010 / 2011$ to $2015 / 2016$. But, the employee interims of required knowledge, skills and attitude are there are a lot of problems. This study shows that most of the problems on manpower are related with the, problems on curriculum (education and training system), employer motivation systems, lacks capacity building, improper practical training centers, poor relation between employer and employee company, are the key constrains on labor forces and related issues on most basic metal manufacturing industries. But well educated, metal industry the engineers and technical talent required to keep the steel industry alive system wise improvement and growing technologically (Table 4).

The table above shows a continually increasing trend in the number of employees working in all industries over the previous six years. The basic metal and engineering industry employed less than $5 \%$ of the employees form the total employed of the country. This implies, metal industry compare to other sectors, in number also small. To sump, this the level of labour force either in number or quality wise it needs more work in the country. As a result, in this stage the performance is not as the expected.

\section{Import/Export performance}

The table above shows the percentage of the cost of imported raw materials to the total cost of all industrial raw materials consumed by metal industries. The table clearly shows that, basic metal industries mainly depend on the imported materials five years. In addition even though iron ore is believed to exist in Ethiopia, it is not mined in the country. Bars and billets are produced from iron ore, coiled wire rods, from which nails are made, and coiled sheets are imported as raw materials (Figure 4 and Table 5).

In addition, as indicted in the above figure, the export performance of metal industries are lowest than other manufacturing sectors. Even though, the metal sub-sector have export shear for the country growth and development but it needs more support. in this study, we found that, lower export performance of metal sectors, occurred due to problems on local row materials, foreign investors are establishing textile factories rather than metal sector, high investment costs for the expansion, product quality, infrastructure constrains are the common challenges of the sectors.

\begin{tabular}{|c|c|c|c|c|c|c|c|}
\hline \multirow[t]{2}{*}{ No } & \multirow[t]{2}{*}{ Type of Product } & \multicolumn{6}{|c|}{ Production Year in ton } \\
\hline & & Base line 2010/11 & 2011/12 2003E.C & 2012/13 & 2013/14 & 2014/15 & 2015/16 \\
\hline 1 & Total predictable Demand & 773297 & 1056960 & 1280124 & 1583481 & 1805310 & 2124288 \\
\hline \multirow[t]{2}{*}{2} & Total Supply & 434270 & 517698.3 & 815300 & 837509.56 & 1317032.9 & 1380496 \\
\hline & Supply-Demand & -339027 & -539261.7 & -464824 & -745971.44 & -488277.1 & -743792 \\
\hline
\end{tabular}

Table 3: The projected demand and supply gap. 
Citation: Dametew AW, Ebinger F (2017) Performance Analysis of Manufacturing Industries for System Improvement. Ind Eng Manage 6: 228. doi:10.4172/2169-0316.1000228

Page 6 of 9

\begin{tabular}{|c|c|c|c|c|c|c|c|}
\hline \multirow[t]{2}{*}{ No. } & \multirow[t]{2}{*}{ Types of sub-sector } & \multicolumn{6}{|c|}{ Man power engaged sub sector } \\
\hline & & $2010 / 11$ & 2011/12 & $2012 / 13$ & 2013/14 & $2014 / 15$ & 2015/16 \\
\hline & Manufacture of basic metals & 4,927 & 3,350 & 3,754 & 3,487 & 7706 & 8206 \\
\hline & $\begin{array}{l}\text { Manufacture of fabricated metal products, except } \\
\text { machinery and equipment }\end{array}$ & 6,040 & 8,421 & 13,396 & 16320 & 17569 & 18709 \\
\hline & Manufacture of machinery and equipment industry & 873 & 653 & 1063 & 1145 & 1233 & 1313 \\
\hline & Manufacture of motor vehicles, trailers and semi-trailers & 1,679 & 1,626 & 3721 & 4008 & 4315 & 4995 \\
\hline \multicolumn{2}{|c|}{ Total } & 16,706 & 13,508 & 26,577 & 28,632 & 30,823 & 32823 \\
\hline
\end{tabular}

Table 4: Number of persons engaged public and private metal and engineering industrial sector.

\title{
Export trade performance in each sub-sector
}

\author{
Metal Sector Lather Textile Cement Other Sector
}

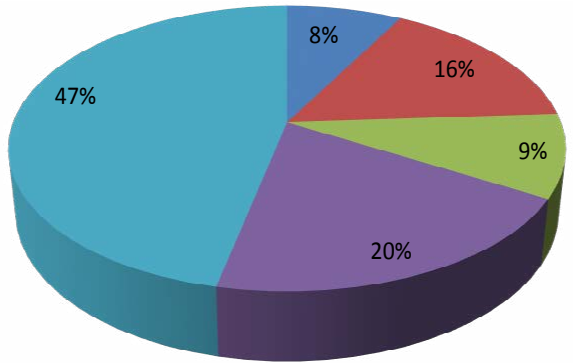

Figure 4: Economic Roles and Export trade performance in each sub-sector.

\begin{tabular}{|c|c|c|c|c|c|c|c|c|c|c|c|}
\hline \multirow[t]{3}{*}{ No } & \multirow[t]{3}{*}{ Types of sub-sector } & \multicolumn{10}{|c|}{ Imported raw material consumption } \\
\hline & & \multicolumn{2}{|c|}{ 2011/12 } & \multicolumn{2}{|c|}{$2012 / 13$} & \multicolumn{2}{|c|}{ 2013/14 } & \multicolumn{2}{|c|}{ 2014/15 } & \multicolumn{2}{|c|}{ 2015/16 } \\
\hline & & Imp & Local & Imp & Local & Imp & Local & Imp & Local & Imp & Local \\
\hline 1 & Manufacture of basic metals & 78.6 & 21.4 & 77.8 & 22.2 & 80 & 20 & 98 & 2 & 64 & 34 \\
\hline 2 & $\begin{array}{l}\text { Manufacture of fabricated metal products, except } \\
\text { machinery and equipment }\end{array}$ & 52.4 & 47.6 & 57 & 43 & 59 & 41 & 52 & 48 & 62 & 38 \\
\hline 3 & Manufacture of machinery and equipment industry & 87 & 13 & 11 & 89 & 67 & 33 & 83 & 17 & 96 & 4 \\
\hline 4 & $\begin{array}{l}\text { Manufacture of motor vehicles, trailers and semi- } \\
\text { trailers }\end{array}$ & 86.6 & 12.3 & 76.6 & 23.4 & 41 & 59 & 49 & 51 & 48 & 52 \\
\hline
\end{tabular}

Table 5: Imported raw material consumption.

\section{Supply chain performance}

Supply chain integration is the strategic integration of both intra- and inter-organizational processes and gauges the extent to which supply chain partners work collaboratively together to gain reciprocally beneficial outcomes. An enormous researches e.g. Hatani et al., investigated the positive impacts of supply chain systems on manufacturing industries. Meanwhile, in this study the Ethiopian manufacturing industry supply chain in trend and practice were investigated. The result shows that, in Ethiopia supply chain systems found as fragmented supply chain, rigid business process, problems on skill man power, outdated technology, poor information exchanges, systems are outdated and paper work, lack of a relevant literature on practical experience in supply chain integration have been the current trends and the challenges of Ethiopia manufacturing firms [6]. The following table also shows that the practices of supply chain systems on Ethiopian manufacturing industries (Table 6). The table above shows the trends and practices of supply chain systems in Ethiopia that addressed by numerous researchers at different times. According to the results the supply chain practices in Ethiopia is infancy, in specific in the case of basic metal sector is fragmental and null $[7,20,21]$. However, this literature analysis found that, infancy, poor and non-integrated supply chain, improper supply chain performance measurement, lacks supply chain integration method and strategies lacks supply chain literature, poor supply chain management practices an $\mathrm{d}$ systems were the common futures of the current Ethiopian manufacturing sectors. Since, due to these problems, the manufacturing efficiency, the performance and global competitiveness manufacturing sectors are weak. As well, because of poor state of infrastructure (transportation problems, electric power, communication, landlocked, internet infrastructure), limited access to finance, limited research and development, poor institutional framework, and inadequate managerial technical skills [22-26], the performance of metal manufacturing industries are low and poor (Table 7).

As a final point, the GDP contribution of manufacturing sectors in the countries are low. As the table above shows that, due the investigated factors, metal sectors have the lowest and list GDP contribution in the country. As result of this performance the overall GDP contribution of the sector is infant and only recorded on $0.4 \%$ of the five light manufacturing sectors (Table 8).

Table above indicates the percentage performance results of each dimension with their measurement indicators. Based on the survey data and analysis of the respondents, field assessment of this study the performance are mainly weighted from higher-low performing levels of the firm were considered. Since the performance levels ranges from (1- 


\begin{tabular}{|c|c|}
\hline $\begin{array}{l}\text { Author and year of } \\
\text { publications }\end{array}$ & Study and findings \\
\hline $\begin{array}{l}\text { Netsanet Jote Tolossa, } \\
2013 \text { [31] }\end{array}$ & $\begin{array}{l}\text { Using literature analysis, the infancy of integration between industrial cluster and supply chain management theories were investigated. } \\
\text { Also shows the needs for further investigations on the role of industrial clusters in a global supply chain management and benchmarking of } \\
\text { best practices manufacturing firms. }\end{array}$ \\
\hline $\begin{array}{l}\text { Fasika Bete Georgise, } \\
2014 \text { [5] }\end{array}$ & $\begin{array}{l}\text { Thorough review of literature and case study in Textile, leather industry analysis result shows that the fragmented supply chain and } \\
\text { business were influences the competitiveness and efficiency of developing country manufacturing firms. In addition, the study found that, } \\
\text { lack of relevant literature, traditional supply chain integration enablers including telephone, fax, and letters, limited to functional bas supply } \\
\text { chain boundaries were investigated as the challenges and constraints of poor supply chain systems of Ethiopian manufacturing firms. }\end{array}$ \\
\hline Beyene, 2015 [22] & $\begin{array}{l}\text { There were problems investigated on green supply chain practices of Ethiopian tanneries in related to green purchasing, marketing } \\
\text { practices, investment recovery, organizational commitment, eco-design and environmental practices are not well considered. Also } \\
\text { customers, supplier reluctance to change towards green supply chain management, lack of government support policies were investigated } \\
\text { challenges of implementing green supply chain management in the sectors. }\end{array}$ \\
\hline $\begin{array}{l}\text { Mengist Hailemariam, } 2010 \\
\text { [30] }\end{array}$ & $\begin{array}{l}\text { The case study in Ethiopian Airports Enterprise (EAE) and Addis Ababa Bole International Airport (AABIA) result identified the five key } \\
\text { areas including corporate culture and decision making, Partnership and collaboration, Airport SC information management system, } \\
\text { Performance measurement, Value adding and optimizing in the airport SC activities were investigated, that needs to emphasizes for } \\
\text { enhancing for improved performance supply chain management processes/practices relevant to the airport industry }\end{array}$ \\
\hline Mebratu, 2013 [28] & $\begin{array}{l}\text { In Ethiopian many firms have not incorporate supply chain management in department level or in their organizational structure and the } \\
\text { practices of supply chain management in Ethiopia is infancy. The survey result shows that, internal (warehouse, Logistics, Inventory related } \\
\text { issue), external (shipment, fragmentally material handling, delay Power fluctuation), and improper ERP System (limited capacity server, } \\
\text { suppliers' capacity to send the documents) were investigated as the main constraints of Ethio-telecom, supply chain process. }\end{array}$ \\
\hline $\begin{array}{l}\text { Fasika Bete Georgise, } \\
2014 \text { [5] }\end{array}$ & $\begin{array}{l}\text { Literature review and questionnaire further investigation show that, due to poor and improper supply chain performance measurement, and } \\
\text { lack of supply chain integration model, the performance and practices of supply chains is poor and low. the study is conducted on, leather } \\
\text { tannery, chemical, garment (lather),beverages ,Food industries }\end{array}$ \\
\hline Lemma, 2015 [27] & $\begin{array}{l}\text { Based on an extensive literature review study, non-price coordination, information and relationship, price coordination, and product } \\
\text { development were investigated the four key constructs of Ethiopian milk suppliers, processors, and retailers on the supply chain process } \\
\text { and practices. }\end{array}$ \\
\hline $\begin{array}{l}\text { Gebreyesus and Denu, } \\
2016 \text { [24] }\end{array}$ & $\begin{array}{l}\text { The study shows the strong relationship between supply chain management (SCM) strategy, SC performance, organizational performance } \\
\text { and the influence of SCM Strategy on organizational and supply chain performances. But the study not shows further for the practices and } \\
\text { trends of supply chain systems in detail. }\end{array}$ \\
\hline Asmamaw, 2016 [21] & $\begin{array}{l}\text { Multiple case study in brewery companies analysis in related to visibility of the inventory status, planning, forecasting and sharing of supply } \\
\text { chain information were investigated as gap for joint relation on breweries with their suppliers and customers. Also, found that, due to limited } \\
\text { local suppliers' capacity and long import process, upstream supply chain systems were less reliable and flexible than the downward supply } \\
\text { chain. This implies that the practices and performance of supply chain process are weak and poor in the sectors. }\end{array}$ \\
\hline
\end{tabular}

Table 6: Ethiopia supply chain management practices investigations.

\begin{tabular}{|c|c|c|}
\hline Sector & Raw material Availability & GDP contribution \\
\hline Metal & 22 million tons of iron ore. & $0.4 \%$ \\
\hline Lather & Cattle $(55.03$ million), sheep $(27.35)$ and goat $(28.16$ million $)$ & $6 \%$ \\
\hline Textile & $2,575,810$ ha land for cotton & $1.41 \%$ \\
\hline Cement & Limestone makes up about $10 \%$ of all sedimentary rocks & NA \\
\hline
\end{tabular}

Table 7: GDP contribution performance in each sub-sector.

\begin{tabular}{|c|c|c|c|c|}
\hline \multirow{2}{*}{$\begin{array}{l}\text { Elements of Manufacturing } \\
\text { Performance dimensions }\end{array}$} & \multirow[t]{2}{*}{ Performance indicator } & \multicolumn{3}{|c|}{ Performance levels (1-6) } \\
\hline & & Low $(0-2)$ & Medium (2-4) & High (4-6) \\
\hline Raw Material & Utilization, quality and quantity & $1.7(4 \%)$ & & \\
\hline Production Capacity & Rate, Varity, Quality, Manufacturing System and Technology & & $2.5(6 \%)$ & \\
\hline Product Demand and Supply & Quality and quantity & & $2.0(5.8 \%)$ & \\
\hline Job Creation And Labor Force & Number of workers, Quality, Capacity building Programs, Turnover & & $3.2(7.6 \%)$ & \\
\hline GDP Contribution & Financial performance, competitiveness, & $1(2.4 \%)$ & & \\
\hline Import-Export Situation & Quality, Quantity, Market Shear & $0.9(2 \%)$ & & \\
\hline Innovation and Technological Capability & $\begin{array}{l}\text { R\&D, Knowledge and Skill, Systems, Experience, Number of new } \\
\text { product development records, }\end{array}$ & $0.7(1.7 \%)$ & & \\
\hline
\end{tabular}

Table 8: The performance situation and capability and with firm performance indicators.

6) for preraiotaization, of higher to performance dimensions. Although, in the above indicates that, even though, in some area the performance is good but the overall of the performance of the sector is poor. Basic metal sector interims of job creation, production verity, some extent product quality is in good condition. But this is insignificant success compared to the other performance indicators, as a result the combined effect of each performance indicator results lower performing capacity sector were found. As assault the performance of the sector in GDP contribution, competitiveness, and sectorial performance is low [27-32].

\section{Summery, Conclusions and Recommendation}

\section{Summery}

The investigation covers the overall assessment of the basic metal manufacturing sector, the practices, overall performance level, identifications of the significance constraints of the sector and the gaps that needs for further studies were incorporated. Meantime, the performance analysis and evaluation measurement provides to, sustain or modifying the process or procedure to increase the output, increase 
efficiency, or increase the effectiveness of the process or procedure [8]. Since this performance study provides to assessing progress toward achieving performance expectations, investigate and explain the causal relationships that exist between program activities and outcomes, correlating the current output to global trends of basic metal sectors were done. Accordingly, in this study, synthesized and analysis for raw material performance, production capacity, product demand and supply, job creation and labor force, GDP contribution, import-export recitation, innovation and technological capability were considered the key performance dimension and each performance dimension also decompose into various performance indicators are considered. Based on the analysis and result the main constrains of Ethiopian basic metal sectors are identified into the following five major groups and related effects.

These are first problems related on Institutional inefficiency: poor in management system, organizational structure, internal integration systems, cheap price for less skill labor force, warehouse problems, poor implementation of advanced improvement systems, poor technological utilization. Second physical constraints: problems in warehouse, improper production infrastructure, the amount and quality of a resource is physically determined and ultimately limits materials availability. The third big challenges are government inefficiency: forging currency problems, infrastructure (electric power, transportation systems, internet access. The fourth system and strategies problems: Forging investor negotiations and licensing or cancelation mechanism, integrated logistics and supply chain problems (sector, national, regional, global level), lack innovation and technology transfer mechanisms, give priority and add some incentives for extracting minerals than other investments. The fifth issue is minor but it needs improvements. This issue is miscellaneous: The level of awareness at each stages (the industry work for the benefits of them, the government and to peoples. As the same time the people or employee work for the success and the improvement of the industry as well as the country rather than monthly payment. Because by default monthly salary will pay at the end of the month. As well, the government contribute to the industries a full role of the government not partials (improve unfairness 'and partiality). Though above are the main challenges currently that hampered and faced for the challenges of the sector. As a result of this the overall of performance, efficiency, and GDP contribution of the sector are poor. Thus, it needs to more efforts to work, to improve the challenges and constraints of the sector and then the Ethiopian basic metal manufacturing sector be competitive at local, regional and global levels. However it is important to develop raw material improvement strategies, production capability, innovation and technology transfer mechanism, lunch proper supply chain integration systems, design marketing strategy to further expand and enter into new markets in the domestic, regional and international market.

\section{Conclusions}

Performance analysis is crucial for any firm in any sector, not only for determining its own efficiency and achievement but also developing further improvement methods and systems. Since, firms should measure their success and failure results because without evaluating and controlling, taking improvement action is usually impossible. Since, this performance analysis study is important and have critical impacts for the overall improvement of the sectors, in which to identify the extent of how much they use their resources to produce or meet the goal and the objectivities of the sectors. This research paper uses industrial survey 86 Ethiopian basic metal sectors and literature review, raw material performance, productivity, technological capability, supply chain integration and job creation and labor force performances were investigated. According to the result high cost of international market, problems forging currency, logistics and public infrastructure, warehouse problems, outdated technology, system are the main constraints of the sectors that reduce the performance and competitiveness of the sectors. Those constraints, the overall performance and GDP contribution of the sector is infant and only recorded on $0.4 \%$ of the five light manufacturing sectors. Although, in this investigation the challenges and constraints grouped in to four themes including institutional inefficiency, physical constraints, government inefficiency, system and strategies problems and miscellaneous and these needs for remedial actions. Based on the findings in this study, several useful managerial insights and implications have been discussed, for the improvement of metal sectors.

\section{Recommendation and further research directions}

Construct on the rich foundation of the research findings described and overall understanding acquired in this study, the authors present the concerns that good point further research and anticipate that these issues may hold the potential in contributing towards the future research studies. The following may require attention from academics and researchers in the future and further work may be carried out.

1. The challenges, constraints and factors of each challenge were identified in the four themes such as sector problems due to institutional inefficiency, physical constraints, government inefficiency, system and strategies problems and miscellaneous with their causes. Since the researcher concern for the solution, the way of improvements for theses constrains, for better basic metal sector.

2. Due to time, financial and other constraints, this study considered 86 medium and large basic metal sector, but further study including from small to large metal manufacturing industries. As well to know the overall manufacturing sector and improve their contributions further study also incorporates other sectors. In the country and regional wise there were small studies were conducted in performance, supply chain and related issues. As a result, the area needs further investigations. Since, academics and researchers may to explore more avenues for quality research both conceptually and empirically to generate more publications in the areas.

\section{References}

1. Geda A (2005) Explaining African Growth Performance: The Case of Ethiopia Addis Ababa.

2. Addis Ababa Chamber of Commerce and Sectoral Association (AACCSA) (2014) An overview of Ethiopian manufacturing, Addis Ababa - Ethiopia.

3. Agency (JICA) (2010) Basic metal and engineering industry Firm-level Study, Addis Ababa Ethiopia.

4. Atalay S (2013) Ethiopian Industrial Development Strategic Plan (2013-2025), FDRE Ministry of Industry, Addis Ababa.

5. Georgise FB (2014) Supply Chain Integration in the Manufacturing Firms in Developing Country: An Ethiopian Case Study. Journal of Industrial Engineering 2014: 1-13.

6. Georgise FB, Dieter TK, Seifert M (2014) Integrating Developing Country Manufacturing Industries into Global Supply Chain. Journal of Industrial Engineering and Management.

7. Georgise FB (2014) Identifying the Characteristics of the Supply Chain Processes in Developing Country: A Manufacturing Industry Perspective. WSEAS TRANSACTIONS on BUSINESS and ECONOMICS 11: 12-31.

8. Kulkarni S (2015) Performance Analysis of Production Line A Case Study in Small Scale Industry. International Journal of Innovative Research in Science, Engineering and Technology 4: 6997-7003. 
Citation: Dametew AW, Ebinger F (2017) Performance Analysis of Manufacturing Industries for System Improvement. Ind Eng Manage 6: 228. doi:10.4172/2169-0316.1000228

Page 9 of 9

9. Kibira1 D, Morris KC, Kumaraguru S (2016) Methods and Tools for Performance Assurance of Smart Manufacturing Systems. Journal of Research of the National Institute of Standards and Technology 121: 287-318.

10. Reichert FM (2014) Technological Capability and Firm Performance. J Techno Manag Innov 9: 20-35.

11. Azubuike VM (2013) Technological Innovation Capability and FirmPerformance in New Product Development. Communications of the IIMA, 13: 43-56.

12. Pour MK (2008) Encyclopedia of Information Science and Technology, Second Edition.

13. Adugna T (2014) Impacts of Manufacturing Sector on Economic Growth in Ethiopia: A Kaldorian Approach. Journal of Business Economics and Management Sciences 1: 1-18.

14. Majumdar S, Asgari B (2017) Performance Analysis of Listed Companies in the UAE-Using DEA Malmquist Index Approach. American Journal of Operations Research 7: 133-151

15. Rao RM (2015) Performance Measurement of Manufacturing industries in Ethiopia- An Analytical Study. Journal of Poverty, Investment and Development 7: $42-54$

16. Mujaddad HG (2016) Measuring efficiency of manufacturing industries in pakistan: An Application of DEA Double Bootstrap Technique. Pakistan Economic and Social Review 54: 363-384.

17. Muzeyin M (2014) Enhancing the Competitiveness of Ethiopian Stee Manufacturing Industries, Addis Ababa: Addis Ababa Univeristy Institute of Technology (AAUiT).

18. Industry FMO (2013) Ethiopian Industrial Development Strategic Plan (20132025), Addis Ababa: FDRE Ministry of Industry.

19. Dametew AW (2017) Technological Innovations as a Potential Vehicle for Supply Chain Integration on Basic Metal Industries. OMICS international, International Journal of Swarm Intelligence and Evolutionary Computation 6: 1-6.

20. Dametew AW (2016) Supply Chain Integration for Improving Performance on Manufacturing Industries. Global Journal of Researches in Engineering:
J-General Engineering 16: 21-34.

21. Asmamaw S (2016) Assessing the perceived performace of supply chainmanagement - the case of two brewery companies in addis ababa, Addis Ababa-Ethiopia: Addis Ababa University.

22. Beyene ZT (2015) Green Supply Chain Management Practices in Ethiopian Tannery Industry: An Empirical Study. International Research Journal of Engineering and Technology (IRJET) 2: 587-598.

23. FDRE (2016) Study of development of iron ore and metallurgy industries in ethiopia: challenges, prospects, and policy/strategy options (2015-2025), Addis Ababa.

24. Gebreyesus N, Denu B (2016) Employees' Perception on the Effects of Supply Chain Management Strategy on Firm Performance The Case of MOHA Soft Drinks Industry S.C. Addis Ababa, Addis Ababa-Ethiopia: Addis Ababa University.

25. Institute (MIDI) Basic metal and Engineering industry performance report, Addis Ababa.

26. Institute MID (2000-2016) Imprort material report.

27. Lemma H (2015) Measuring Supply Chain Coordination in Milk and Dairy Industries: AConfirmatory Factor Model. International Journal of Economics \& Management Sciences 4: 1-7.

28. Mebratu (2013) Prospects and challenges of supply chain management in ethio telecom, Addis Ababa Ethiopia: St. Mary's university.

29. Megazine AF (2016) Local Companies to Supply Long Overdue Steel, Addis Ababa Ethiopia: Fortune.

30. Hailemariam KJM (2010) Managing Airport Supply Chain: an Ethiopian case study. POMS 21st Annual Conference, Vancouver, Canada.

31. Tolossa NJ (2013) A Review on the Integration of Supply Chain Management andIndustrial Cluster. International Journal of Marketing Studies 5: 164-174.

32. The Federal Democratic Republic of Ethiopia Central Statistical Agency, 2010-2016. Report on Large and Medium Scale Manufacturing and Electricity Industries Survey, Addis Abab. 